\title{
BİST'te İşlem Gören Mevduat Bankalarının IMF Finansal Sağlamlık Göstergeleri Açısından Topsis ve Entropi Yöntemleri ile Analizi
}

Mehmet Mete KARADAĞ $\breve{G}^{1}$

Makale Gönderim Tarihi: 12 Temmuz 2021

Makale Kabul Tarihi: 15 Eylül 2021

$\ddot{O} z$

Bu çalışmanın amacı, Borsa İstanbul'da işlem gören mevduat bankalarının finansal sağlamlıklarının çok kriterli karar verme yöntemlerinden TOPSİS ve Entropi Yöntemleriyle değerlendirilmesidir. Çalışmada IMF finansal sağlamlık göstergelerinden ve Borsa İstanbul'da işlem gören mevduat bankalarının 2018 yılına ilişkin verilerinden yararlanılmıştır. Çalışmanın ilk aşamasında Entropi yöntemi kullanılarak kriterlerin ağırlıkları saptanmış; ardından TOPSİS yöntemi ile finansal sağlamlık açısından bankaların sıralaması yapılmıştır. Çalışma sonucunda IMF finansal sağlamlık göstergeleri açısından 2018 y1lı verilerine göre ilk sırada QNB Finansbank A.Ş.; ikinci sırada ise Yap1 ve Kredi Bankası A.Ş. yer almıştır.

Anahtar Kelimeler: Finansal Sağlamlık Göstergeleri, TOPSİS, Entropi

JEL Kodları: C44, G17, G21

1 Dr. Öğr. Üyesi, İstanbul Aydın Üniversitesi, metekaradag@aydin.edu.tr, ORCID: 0000-0001-80639151 


\title{
Analysis of the Deposit Banks Quoted in BIST With Topsis and Entropy Methods in Terms of IMF Financial Soundness Indicators
}

\begin{abstract}
The purpose of this study is to evaluate the financial soundness of the deposit banks quoted in BIST by using Entropi and TOPSIS methods which are multi-criteria decision making methods. In the study, IMF financial soundness indicators and 2018 data of deposit banks traded on Borsa Istanbul were used. In the first stage of the study, the weights of the criteria were determined using the Entropy method; then, the banks were ranked in terms of financial soundness with the TOPSIS method. As a result of the study, QNB Finansbank ranked first in terms of IMF financial strength indicators according to 2018 data. In second place, Yap1 ve Kredi Bankası A.Ş. took place.
\end{abstract}

Keywords: Financial Soundness Indicators, TOPSIS, Entropy

JEL Codes: C44, G17, G21

\section{Giriş}

Ekonomide bankalar, fon fazlasına sahip ekonomik birimlerden fon aç1ğına sahip ekonomik birimlere fon aktarımının gerçekleştirilmesini sağlayan en önemli finansal kurumların başında gelmektedir. Türkiye'de de finansal piyasalarda fon aktarımını sağlayan başlıca kurumlar bankalardır. Türkiye'de bankaların ağırlıkta olduğu bir finansal sistem vardır.

Sağlam, etkin bir şekilde işleyen finansal sistemler fonların verimli yatırım projelerine aktarılmasını sağlayarak ekonomik gelişmeye katkıda bulunurlar. Finansal sistemlerin en etkili ve önemli oyuncuları arasında olan bankaların finansal sağlamlığ da finansal sistemde etkin bir fon transferinin gerçekleştirilmesinde ve sonuçta ekonomik büyüme ve gelişmenin sağlanmas1 açısından son derece önemlidir.

$\mathrm{Bu}$ çalışmada IMF tarafindan mevduat kabul eden kuruluşlar için temel set olarak kabul edilen 12 finansal sağlamlık göstergesinden, veri eksikliği olan 1 gösterge çıkartılmıştır. Çalışmada, 11 finansal gösterge dikkate alınarak Borsa İstanbul'da işlem gören mevduat bankalarının finansal sağlamlıklarının çok kriterli karar verme (ÇKKV) yöntemlerinden TOPSİS ve Entropi yöntemleriyle değerlendirilmesi amaçlanmıştır. Çalışmada yararlanılan kriterlerin ağırlıkları Entropi yöntemi kullanılarak belirlenmiştir. Daha sonra TOPSİS yöntemi kullanılarak bankaların performans sıralamaları yapılmıştır. 
Çalışmada sadece bir yıllık dönem değerlendirilmiştir. Çalışmada 2018 yılı finansal verilerinden yararlanılarak sağlamlıkları değerlendirilen bankalar 10 tanedir.

\section{Finansal Sağlamlık Göstergeleri}

Sağlam bir bankacılık sistemi, çoğu bankanın (sistemin varlık ve yükümlülüklerinin çoğunu oluşturanlar) yükümlülüklerini karşılama yeteneğine sahip olduğu ve muhtemelen böyle kalacağı bir sistem olarak tanımlanabilir (Lindgren, Garcia and Saal, 1996).

Finansal sağlamlık göstergeleri, bir ülkedeki finansal kurumların ve bunların şirket ve hane halkları karşılıklarının mevcut finansal sağlık ve sağlamlığının göstergeleri olup; finansal istikrarı artırmak ve özellikle finansal sistemin başarısız olma olasılığını azaltmak için finansal sistemlerin güçlü ve zayıf yönlerinin değerlendirilmesine ve izlenmesine yardımcı olmak amacıyla hesaplanmaktadır (IMF, 2006). 2001 yılında IMF Yürütme Kurulu'nca ülkelerin finansal kuruluşlarının sağlığı ve sağlamlığına dair bir fikir sağlamak amacı ile temel ve önerilen setlerden oluşan finansal sağlamlık göstergeleri yayımlanmıştır (IMF, 2015).

IMF finansal sağlamlık göstergeleri temel ve önerilen set olarak ikiye ayrılmaktadır. Mevduat kabul eden kuruluşlarla ilgili temel set 12 göstergeden oluşmaktadır (IMF, 2006). Finansal sağlamlık göstergeleri temel seti Tablo 1'de yer almaktadir:

Tablo 1. Finansal Sağlamlık Göstergeleri: Temel Set

\begin{tabular}{|c|c|}
\hline Mevduat kabul eden kuruluşlar & \\
\hline Sermaye yeterliliği & $\begin{array}{l}\text { Yasal Özkaynak / Risk Ağırlıklı Varlıklar } \\
\text { Birinci Kuşak Sermaye / Risk Ağırlıklı Varlıklar } \\
\text { Net Takipteki Alacaklar / Sermaye }\end{array}$ \\
\hline Aktif kalitesi & $\begin{array}{l}\text { Takipteki Alacaklar / Toplam Brüt Krediler } \\
\text { Kredilerin Sektörel Dağ } 11 \text { ımı / Toplam Krediler }\end{array}$ \\
\hline \multirow[t]{4}{*}{ Getiriler ve karlılık } & Net Kâr / Toplam Aktifler \\
\hline & Net Kâr / Özkaynaklar \\
\hline & Faiz Marj1 / Brüt Gelir \\
\hline & Faiz Dışı Giderler / Brüt Gelir \\
\hline Likidite & \begin{tabular}{|l} 
Likit Aktifler / Toplam Aktifler \\
Likit Aktifler / Kısa Vadeli Yükümlülükler
\end{tabular} \\
\hline Piyasa riskine duyarlllık & Yabancı Para Net Açık Pozisyonu / Sermaye \\
\hline
\end{tabular}

Kaynak: IMF (2006), Financial Soundness Indicators Compilation Guide, https://www.imf.org/external/pubs/ft/fsi/guide/2006/pdf/fsiFT.pdf, s.2, Erişim Tarihi: 09.09.2017. 


\section{Literatür Taraması}

Demireli (2010) çalışmasında 2001-2007 yılları arasındaki 7 yıllık dönemde Türkiye'de faaliyet gösteren kamu sermayeli bankaların performanslarının TOPSIS yöntemiyle belirlenmesini amaçlamıştır. Çalışma sonucunda yurt çapında yaygın olarak faaliyet gösteren kamu sermayeli bankaların yerel ve global finansal krizlerden etkilendiği, performans puanlarının yurtdışı verilere dayalı olarak sürekli olarak dalgalanmalar gösterdiği, bankacılık sektöründe göze çarpan bir iyileşmenin kaydedilemediği saptanmıştır.

Tunay ve Akhisar (2015) çalışmalarında Türkiye'deki özel ticari bankaların 2009-2013 dönemindeki performans değerlendirmesini ve siralamas1$\mathrm{n}$ 1 TOPSİS ve AHP yöntemleriyle yapmışlardır.

Gündoğdu (2015) çalışmasında 16 kriter esas alarak, Türkiye'de faaliyette bulunan 10 yabancı bankanın 2003-2013 yılları arasındaki finansal performanslarını TOPSİS yöntemi kullanarak ölçmeyi amaçlamıştır.

Kandemir ve Karataş (2016) çalışmalarında Borsa İstanbul'da işlem gören 12 mevduat bankasının 2004-2014 yılları arasındaki finansal performanslarını Çok Değişkenli Karar Verme yöntemleriyle incelemişlerdir. Çalışmada Gri ilişkisel analiz, TOPSIS ve VIKOR analiz yöntemleri kullanılmıştır. Bankaların finansal performanslarını değerlendirmek için literatürde kabul görmüş ve önemli kabul edilen toplam 18 tane finansal oran belirlenmiştir.

Eyüboğlu (2016) çalışmasında 2009-2013 dönemi için TOPSİS yöntemi ile yedi gelişmekte olan ülke (Arjantin, Brezilya, Endonezya, Polonya, Rusya, G.Afrika ve Türkiye) bankacılık sektörünün finansal performanslarının karşılaştırmayı amaçlamıştır. Performans ölçümünde IMF Finansal Sağlamlık göstergeleri içerisinde yer alan on finansal rasyodan faydalanılmıştır.

Yıldırım ve Demirci (2017) çalışmalarında 32 finansal oran belirleyerek Borsa İstanbul (BIST)'da işlem gören ve bankacılık sektöründe faaliyet gösteren kamu ve özel sermayeli 10 bankanın 2015 y1lı finansal performans değerlendirmesini TOPSIS ve TOPSIS-Mahalanobis (TOPSIS-M) yöntemlerini kullanarak yapmışlar ve bankaları finansal performanslarına göre sıralamışlardır. Bu çalışmada katılım bankaları çalışmaya dahil edilmemiştir.

Kenger ve Organ (2017) çalışmalarında ÇKKV yöntemleri ile bankaya alınacak en uygun personelin seçimi amaçlamışlar; Hatay ilinde yapılan bu çalışmada, işe başvuran beş aday, üç farklı karar verici tarafından personel seçimi için on kriterin önem dereceleri dikkate alınarak değerlendirilmiştir. Öncelikle, Entropi yöntemi ile personelin kriterler ağırlıkları hesaplanarak, kriterlerin önem dereceleri sıralanmıştır. Daha sonra elde edilen veriler çerçe- 
vesinde, Additive Ratio Assesment (ARAS) yöntemi uygulanarak, bankaya iş için başvuran alternatif adaylar değerlendirilerek banka için en uygun personel adayı belirlemeye çalışmışlardır.

Aldemir ve Özden (2017) çalışmalarında çok kriterli karar verme yöntemlerinden TOPSIS ve VIKOR yöntemini kullanarak Türkiye'de 2016 yılı sonu itibarıyla faaliyet gösteren mevduat bankalarının 2012-2016 yılları arasındaki finansal performanslarını yıllık bazda değerlendirmiş ve sıralanmışlardır. Veri eksikliği olan ve TMSF'de bulunan bankalar değerlendirmeden hariç tutulmuştur. Farklı yapıda olmaları nedeniyle katılım bankaları ile kalkınma ve yatırım bankaları performans değerlendirmesine dahil edilmemiştir.

Ayaydın, Çam, Pala ve Sarı (2018) çalışmalarında AHS (Analitik Hiyerarşi Süreci) ve TOPSİS yöntemlerini kullanarak Türkiye'de faaliyet gösteren 29 mevduat bankasının 2011-2013 yılları için performans değerlemesini yapmışlardır. Çalışmada sermaye yeterliliği, bilanço yapısı, aktif kalitesi, likidite, karlılık, gelir gider yapısı, sektör payları, grup payları ve şube rasyoları olmak üzere toplam 34 rasyo performans alt kriteri olarak kullanılmıştır.

Ural, Demireli ve Özçalık (2018) çalışmalarında çok kriterli karar verme tekniklerinden Entropi ve WASPAS yöntemleri kullanarak Türkiye'de faaliyet gösteren 3 adet kamu sermayeli bankanın performanslarını, 2012-2016 dönemine ait temel finansal tablolarından sağlanan veriler ile incelemişlerdir.

Vergili (2018) çalışmasında BIST’te işlem gören bankaların, CAMELS kriterlerine dayanan 6 kategoriden (sermaye yeterliliği, aktif kalitesi, yönetim kalitesi, karlılık, likidite, piyasa riskine duyarlılık) seçilen 15 adet oranla 2009-2013 dönemi verilerine dayalı olarak finansal performanslarını ölçmüştür. 15 adet oranının ağırlıklarının belirlenmesinde banka müdürlerinin ve akademisyenlerin yapmış oldukları puanlamalar ele alınarak Analitik Hiyerarşi Proses (AHP) yönteminden yararlanılmıştır. Performans puanlarının hesaplanmasında TOPSIS yöntemi kullanılmıştır.

Uludağ ve Ece (2018) çalışmalarında Türkiye'de faaliyet gösteren 28 adet mevduat bankasının, 2006-2016 yılları arasındaki finansal performansları sermaye yeterliliği, büyüklük, karlılık, aktif kalitesi, likidite, büyüme oranı ve risk olmak üzere 7 ana başlık altında toplanan 49 alt kritere göre değerlendirilmiştir. Analizde mevduat bankaları; kamu, özel ve yabancı sermayeli mevduat bankaları olmak üzere 3 ana grup şeklinde sınıflandırılmıştır. Bu çalışmada, mevduat bankalarının finansal performanslarının değerlendirilmesinde TOPSİS yöntemi kullanılmıştır. 
Işık (2019), çalışmasında Türk mevduat bankacılığı sektörünün 2008-2017 yılları arasındaki finansal performansını değerlendirmek amacıyla sektörün 2008-2017 yılları arasındaki performansını 8 değerlendirme kriteri (sermaye yeterlilik oranı, mevduat-varlık oranı, kredi-varlık oranı, takibe düşen krediler oranı, likit varlık oranı, aktif karlılığı, faiz dışı gelirler oranı ve etkinsizlik oranı) kullanarak çok kriterli karar verme (ÇKKV) yöntemleriyle değerlendirmiştir. Çalışmada değerlendirme kriterleri için ağırlıklar Entropi yöntemine göre hesaplanmış ve yıllara ilişkin performans değerlendirmesi için ise ARAS (Additive Ratio Assesment) yöntemi kullanılmıştır.

Ayçin ve Orçun (2019) çalışmalarında Türkiye'de faaliyet gösteren mevduat bankalarının performanslarının Entropi ve MAIRCA (MultiAtributive Ideal-Real Comparative Analysis) yöntemleri ile değerlendirilmesini amaçlamışlardır. Bu kapsamda, Türkiye'de faaliyet gösteren ve şube sayısı 500'ün üzerinde olan mevduat bankaları analize dahil etmişlerdir. Toplam aktifler, toplam krediler ve alacaklar, toplam mevduat, toplam özkaynaklar, şube sayısı ve çalışan sayısı kriterleri baz alınarak, bankaların 2016 ve 2017 yıllarına ilişkin performansları değerlendirilmiştir.

Akgül (2019), çalışmasında ÇKKV yöntemlerinden SAW, MAUT ve ARAS yöntemlerini kullanarak 2010-2018 yıllarını kapsayan dönem için Türk bankacılık sisteminin seçilen finansal göstergelere dayalı finansal performansını analiz etmiştir. Çalışmada öncelikle belirlenen kriterlerin ağırlıkları Entropi yöntemi kullanılarak hesaplanmıştır. Entropi yöntemi sonucunda Türk bankacılık sistemi için en önemli üç performans kriterinin sırasıyla likit aktifler/kısa vadeli yükümlülükler, alınan krediler/toplam varlıklar ve duran varlıklar/toplam varlıklar kriterleri olduğu görülmüştür. Sonrasında Entropi yöntemi ile elde edilen ağırlıklar SAW, MAUT ve ARAS modellerine aktarılarak yıllık bazda bankacılık sisteminin finansal performans siralaması yapılmıştır. Çalışma sonucunda ise Türk bankacılık sisteminin en iyi performans gösterdiği yılın 2010 yılı olduğu bununla beraber en kötü performans gösterdiği yılın ise 2018 yılı olduğu tespit edilmiştir.

Karaca, Çevik ve Altemur (2019) çalışmalarında Borsa İstanbul 30 endeksinde işlem gören 6 mevduat bankasının finansal performanslarını, ilgili literatür incelenerek belirlenen 20 adet finansal oran aracılığıyla TOPSIS yöntemi ile inceleyerek sıralamaya tabi tutmuşlardır.

Selimler ve Karadağ (2020) çalışmalarında IMF tarafından oluşturulan finansal sağlamlık göstergelerinden yararlanarak Türkiye ile 2004 yılı ve sonras1 Avrupa Birliği’ne üye olan, aday olan ve potansiyel aday toplam 19 ülkeye ait 2018 verilerini kullanmışlardır. Çalışmada, 12 temel kriterin ağırlıkları 
Entropi yöntemi ile tespit edilmiş, daha sonra EDAS yöntemi ile ülkelerin finansal sağlamlık göstergelerine göre performans sıralaması yapılmıştır.

\section{Araştırmanın Kapsamı ve Amacı}

Türk Bankacılık Sektöründe Aralık 2018 itibarıyla; 34 Mevduat, 13 Kalkınma ve Yatırım, 5 Katılım bankası olmak üzere toplam 52 banka faaliyet göstermektedir (BDDK, 2019). Mevduat bankalarının aktiflerinin sektör içindeki payı yüzde 88 , kalkınma ve yatırım bankalarının payı yüzde 7 , katılım bankalarının payı ise yüzde 5 olmuştur. Kamu sermayeli mevduat bankalarının payı yüzde 32, özel sermayeli mevduat bankalarının payı yüzde 33, yabancı sermayeli mevduat bankalarının payı ise yüzde 22'dir (TBB, 2019a).

Araştırmanın kapsamını Borsa İstanbul'da işlem gören mevduat bankaları oluşturmaktadır. İşlem gören kalkınma ve yatırım bankaları ile katılım bankaları araştırmaya dahil edilmemişlerdir. Çalışmada sadece bir yıllık dönem değerlendirilmiştir. Çalışmada 2018 yılı verilerinden yararlanılarak sağlamlıkları değerlendirilen bankalar 10 tanedir. Analizde yer alan bankaların listesi Tablo 2'de yer almaktadır.

Tablo 2. Borsa İstanbul'da İşlem Gören Mevduat Bankaları

\begin{tabular}{|l|l|c|}
\hline \multirow{2}{*}{ Mevduat Bankalart } & Banka Adı & $\begin{array}{c}\text { BiST } \\
\text { Kodu }\end{array}$ \\
\hline \multirow{3}{*}{ Kamu Sermayeli } & Türkiye Vakıflar Bankası T.A.O. & TVB \\
\cline { 2 - 3 } & Türkiye Halk Bankası A.Ş. & THL \\
\hline \multirow{5}{*}{ Özel Sermayeli } & Akbank T.A.Ş. & AKB \\
\cline { 2 - 3 } & Şekerbank T.A.Ş. & SEK \\
\cline { 2 - 3 } & Türkiye İş Bankası A.Ş. & TIB \\
\cline { 2 - 3 } & Yapı ve Kredi Bankası A.Ş. & YKB \\
\hline \multirow{5}{*}{ Yabancı Sermayeli } & Denizbank A.Ş. & DNZ \\
\cline { 2 - 3 } & QNB Finansbank A.Ş. & FIN \\
\cline { 2 - 3 } & Türkiye Garanti Bankası A.Ş. & TGB \\
\cline { 2 - 3 } & ICBC Turkey Bank A.Ş. & ICB \\
\hline
\end{tabular}

Kaynak: Borsa İstanbul (2019), Üye Bilgileri, https:/www.borsaistanbul.com/borsa_uyeleri/uye-bilgileri?g=3\&y=205, (Erişim Tarihi: 28.10.2019).

Aralık 2018 itibariyle, Borsa İstanbul'da işlem gören mevduat bankalarının toplam banka aktifleri içindeki payı (katılım bankaları hariç) $\% 68,46$; toplam krediler içindeki payı \%66,03; toplam mevduat içindeki payı \%72,92'dir (TBB, 2019b). Araştırmaya dahil edilen bankaların 31.12.2018 itibariyle aktif büyüklüklerine göre sıralaması Tablo 3 'te yer almıştır. 
Tablo 3. Araştırmaya Dahil Edilen Bankaların 31.12.2018 İtibariyle Aktif Büyüklüklerine Göre Sıralaması (Milyon TL)

\begin{tabular}{|c|c|c|c|c|c|c|c|c|c|}
\hline Banka & $\begin{array}{l}\text { Toplam } \\
\text { Aktifler }\end{array}$ & $\begin{array}{l}\text { Toplam } \\
\text { Krediler* }\end{array}$ & $\begin{array}{c}\text { Toplam } \\
\text { Mevduat }\end{array}$ & $\begin{array}{c}\text { Toplam } \\
\text { Özkaynaklar }\end{array}$ & $\begin{array}{l}\text { Ödenmiş } \\
\text { Sermaye }\end{array}$ & $\begin{array}{c}\text { Net } \\
\text { Dönem } \\
\text { Kar/Zararı } \\
\end{array}$ & $\begin{array}{l}\text { Bilanço Dışı } \\
\text { Hesaplar }\end{array}$ & $\begin{array}{l}\text { Şube } \\
\text { Sayısı } \\
\text { (Adet) }\end{array}$ & $\begin{array}{l}\text { Çalışan } \\
\text { Sayısı } \\
\text { (Adet) }\end{array}$ \\
\hline Türkiye İş Bankası A.Ş. & 416.388 & 260.195 & 245.269 & 49.721 & 4.500 & 6.769 & 1.220 .575 & 1.355 & 24.570 \\
\hline $\begin{array}{l}\text { Türkiye Halk Bankası } \\
\text { A.Ş. }\end{array}$ & 378.422 & 250.624 & 248.855 & 29.021 & 1.250 & 2.522 & 1.422 .433 & 994 & 18.781 \\
\hline $\begin{array}{l}\text { Türkiye Garanti Bankası } \\
\text { A.Ş. }\end{array}$ & 359.477 & 223.288 & 218.058 & 46.688 & 4.200 & 6.638 & 1.920 .000 & 934 & 18.338 \\
\hline $\begin{array}{l}\text { Yapı ve Kredi Bankası } \\
\text { A.Ş. }\end{array}$ & 348.044 & 211.338 & 202.549 & 39.003 & 8.447 & 4.667 & 4.372 .999 & 854 & 17.577 \\
\hline $\begin{array}{l}\text { Türkiye Vakıflar Bankası } \\
\text { T.A.O. }\end{array}$ & 331.356 & 221.547 & 179.408 & 28.350 & 2.500 & 4.154 & 3.010 .040 & 951 & 16.767 \\
\hline Akbank T.A.Ş. & 327.642 & 185.125 & 188.391 & 43.809 & 4.000 & 5.690 & 1.843 .990 & 781 & 13.367 \\
\hline QNB Finansbank A.Ş. & 157.416 & 94.018 & 87.090 & 14.572 & 3.350 & 2.410 & 1.148 .541 & 542 & 12.276 \\
\hline Denizbank A.Ş. & 137.658 & 87.176 & 84.129 & 15.445 & 3.316 & 2.183 & 916.381 & 711 & 11.786 \\
\hline Şekerbank T.A.Ş. & 31.321 & 20.564 & 23.089 & 2.377 & 1.158 & 86 & 674.836 & 273 & 3.571 \\
\hline ICBC Turkey Bank A.Ș. & 15.519 & 7.621 & 8.208 & 1.122 & 860 & 62 & 33.212 & 44 & 786 \\
\hline
\end{tabular}

Kaynak: TBB (2019a), Bankalarımız 2018, Yayın No: 331, https://www.tbb.org.tr/Content/Upload/Dokuman/7604/Bankalarimiz_2018.pdf.

Araştırmada yararlanılan veriler, TBB web sitesinde yer alan seçilmiş rasyolardan ve finansal tablolardan elde edilmiştir.

Bu çalışmanın amacı, Borsa İstanbul'da işlem gören mevduat bankalarının 2018 yılı finansal verilerinden yararlanılarak ÇKKV yöntemlerinden TOPSİS yöntemi ve Entropi yöntemi kullanılarak IMF finansal sağlamlık göstergelerine göre finansal sağlamlıklarının belirlenmesi ve bankalar arası siralamanın yapılmasıdır.

\section{Araştırmanın Verileri ve Metodoloji}

Araştırmada IMF'nin finansal sağlamlık göstergelerinden yararlanılarak finansal sağlamlığ ölçmede kullanılacak 11 oran belirlenmiştir. Türkiye Bankalar Birliği (TBB) ve Bankacılık Düzenleme ve Denetleme Kurumu'nun (BDDK) web sitelerinde yer alan veriler kullanılarak oranlar hesaplanmıştır. Bazı oranlar ise bu kurumların web sitelerinden hazır olarak alınmıştır.

IMF Finansal Sağlamlık Göstergeleri'ne göre oluşturulan Finansal Sağlamlık Oranları (değerlendirme kriterleri), kodları ve etki yönleri Tablo 4'te gösterilmiştir. Pozitif değer değişkenler yükseldiğinde endeksin yükseleceğini; negatif değer ise değişkenler yükseldiğinde endeksin düşeceğini ifade etmektedir. 
Tablo 4. Finansal Sağlamlık Oranları, Kodları ve Etki Yönleri

\begin{tabular}{|c|c|c|c|}
\hline Grup & Kriterler & Kod & Etki Yönü \\
\hline \multirow[t]{3}{*}{$\begin{array}{l}\text { Sermaye } \\
\text { Yeterliliği }\end{array}$} & $\begin{array}{l}\text { Sermaye Yeterliliği Oranı (Özkaynaklar / (Toplam Risk } \\
\text { Ağırlıklı Tutarlar)*100) }\end{array}$ & $\mathrm{O} 1$ & + \\
\hline & Ana Sermaye / Risk Ağırlıklı Tutar & $\mathrm{O} 2$ & + \\
\hline & $\begin{array}{l}\text { Takipteki Krediler (Net) / Yasal Özkaynak² } \\
\text { (donuk alacaklar-özel karş1lıklar)/ Yasal Özkaynak }\end{array}$ & O3 & - \\
\hline Aktif Kalitesi & $\begin{array}{l}\text { Takipteki Krediler / Toplam Krediler ve Alacaklar }{ }^{3} \\
\text { Donuk alacaklar/ Toplam Krediler ve Alacaklar }\end{array}$ & O4 & - \\
\hline \multirow{4}{*}{$\begin{array}{l}\text { Getiriler ve } \\
\text { Karlılık }\end{array}$} & Aktif Karlılık Oranı $(\mathrm{ROA})^{4}$ & O5 & + \\
\hline & Özkaynak Karlılık Oranı $(\mathrm{ROE})^{5}$ & O6 & + \\
\hline & Net Faiz Geliri / Brüt Gelir ${ }^{6}$ & $\mathrm{O} 7$ & + \\
\hline & Faiz Dışı Giderler / Brüt Gelir ${ }^{7}$ & O8 & - \\
\hline \multirow[t]{2}{*}{ Likidite } & Likit Aktifler / Toplam Aktifler & O9 & + \\
\hline & Likit Aktifler / Kısa Vadeli Yükümlülükler & $\mathrm{O} 10$ & + \\
\hline $\begin{array}{l}\text { Piyasa Riskine } \\
\text { Duyarl1l1k }\end{array}$ & $\begin{array}{l}\text { (Net Bilanço Pozisyonu + Net Nazım Hesap Pozisyonu) / Öz- } \\
\text { kaynak }\end{array}$ & O11 & - \\
\hline Açıklamalar: & \multicolumn{3}{|c|}{ 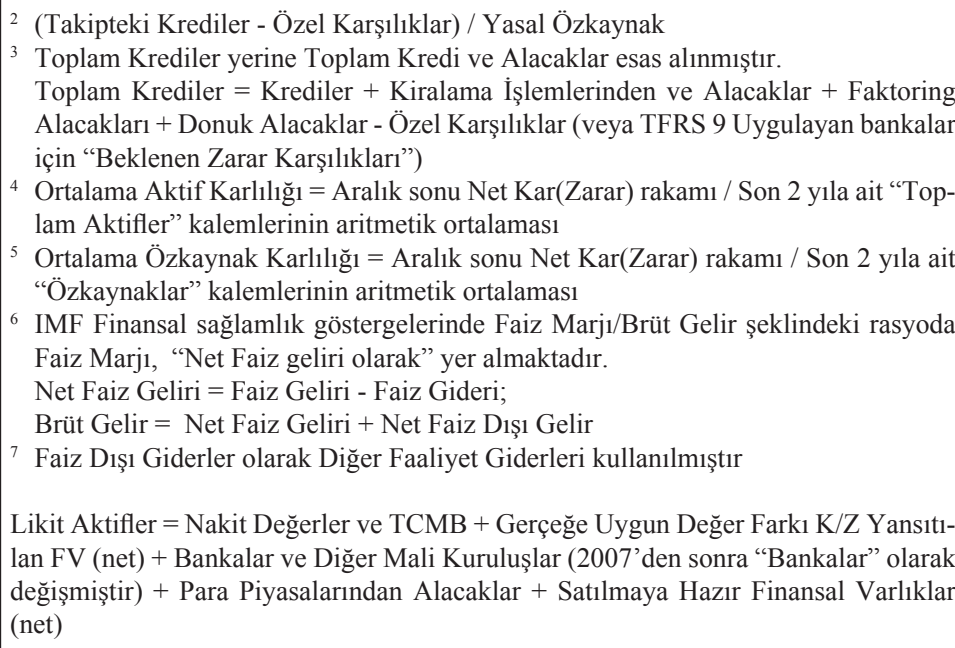 } \\
\hline
\end{tabular}

Kaynak: TBB (2019c), IMF, BDDK ve TBB verilerinden yararlanılarak yazar tarafından oluşturulmuştur.

Çok kriterli karar verme problemlerinin çözümüne yönelik kullanılan pek çok yöntem mevcuttur. Basit ve pratik bir yöntem olduğu için çalışmada çok kriterli karar verme yöntemlerinden biri olan TOPSIS yöntemi kullanılmiştır. 
Kriter ağırlıklarının belirlenmesinde sübjektif ya da objektif yöntemler kullanılabilir. Bu çalışmada sonuçların güvenilirliği açısından kriter ağırlıklar1 sübjektif olarak belirlenmek yerine objektif ağırlıklandırma yöntemlerinden Entropi yöntemi kullanılarak belirlenmiştir.

\subsection{Entropi Yöntemi}

Bilgi entropisi, Shannon tarafindan 1948 tarihli "A Mathematical Theory of Communication" başlıkı çalışmasında tanımlanan bir belirsizlik ölçüsü olup, mühendislik, yönetim ve benzeri gibi birçok alanda yaygın olarak kullanılmaktadır (Wu, Sun, Liang, \& Zha, 2011). Shannon entropisi, olasılık teorisi açısından formüle edilmiş, bilgilerdeki belirsizliğin bir ölçüsüdür (Wang \& Lee, 2009). Entropi ağırlığı, belirli bir özellik açısından birbirlerine ne kadar farklı alternatiflerin yaklaştı̆̆ını açıklayan bir parametredir. Entropinin değeri ne kadar büyük olursa, entropi ağırlığı o kadar küçük olur (Entropinin değeri arttıkça, entropi ağırlığı azalır), o zaman bu belirli özellikteki farklı alternatifler o kadar küçük olur ve belirli özellik ne kadar az bilgi sağlarsa bu özellik karar verme sürecinde o kadar az önem kazanır (Wang \& Lee, 2009). 2019):

Entropi yönteminin adımları ve ilgili değişkenler aşağıdaki gibidir (Ayçin,

$\mathrm{A}_{i}: i$. karar alternatifi $(i=1,2, \ldots, m)$

$\mathrm{C}_{j}: j$. değerlendirme kriteri $(j=1,2, \ldots, n)$

$x_{i j}: j$. değerlendirme kriterine göre $i$. alternatifin aldığ 1 değer

$p_{\mathrm{ij}}$ : değerlendirme kriterine göre $i$. alternatifin aldığı normalize değer

$k$ : entropi katsayısı

$e_{j}$ : entropi değeri

$d_{j}$ : farklılaşma derecesi

$w_{j}$ : ağırlık değeri, $(j=1,2, \ldots, n)$

\section{Birinci Adım: Karar Matrisinin Oluşturulması}

$x_{i j}$ değerlerinden oluşan ve $m$ adet alternatiften; $n$ adet kriterden oluşan $D$ karar matrisi Eşitlik (1)'deki gibi oluşturulur.

$$
D=\left[\begin{array}{cccc}
x_{11} & x_{12} & \cdots & x_{1 n} \\
x_{21} & x_{22} & \cdots & x_{2 n} \\
\vdots & \vdots & \cdots & \vdots \\
x_{m 1} & x_{m 2} & \cdots & x_{m n}
\end{array}\right]
$$


$i=1,2, \ldots, m$ ve $j=1,2, \ldots, n$

\section{İkinci Adım: Karar Matrisinin Normalleştirilmesi}

Karar problemlerinde yer alan farklı birimlere sahip kriterlere ilişkin değerler, normalleştirme işlemiyle [0,1] aralığında değer alacak biçimde standart hale getirilir. Eşitlik (2)'den yararlanarak normalleştirme işlemi yapılır.

$$
p_{i j}=\frac{x_{i j}}{\sum_{i=1}^{m} x_{i j}} \forall i, j
$$

\section{Üçüncü Adım: Kriterlere İlişkin Entropi Değerlerinin Bulunması}

Her bir değerlendirme kriterinin entropi değerleri $\left(e_{j}\right)$ Eşitlik (3)'den yararlanılarak hesaplanır.

$$
e_{j}=-k \cdot \sum_{j=1}^{m} p_{i j} \cdot \ln \left(p_{i j}\right)
$$

$k=1 / \ln (m) \quad$ şeklinde hesaplanır. nimlanir.

$\mathrm{e}_{j}$ değeri $j$. kriterin belirsizlik ölçüsü ya da "entropi değeri” olarak ta-

\section{Dördüncü Adım: Farklılaşma Derecelerinin Bulunması}

Farklılaşma dereceleri $\left(d_{j}\right)$ olarak ifade edilmektedir. $d_{j}$ değerleri her bir kriter için daha önce bulunan entropi değerleri kullanılarak Eşitlik (4)'ten yararlanılarak bulunur.

$$
d_{j}=1-e_{j} \quad j=1,2, \ldots, n
$$

\section{Beşinci Adım: Entropi Kriter Ağırlıklarının Hesaplanması}

Her bir kriterin farklılaşma derecesini, toplam farklılaşma derecesine oranlayarak kriterlerin ağırlık değerleri $\left(w_{j}\right)$ bulunur.

$$
\begin{aligned}
& w_{j}=\frac{d_{j}}{\sum_{j=1}^{n} d_{j}} \\
& \sum_{j=1}^{n} w_{j}=1 \text { Kriterlerin ağırlıklarının toplamı bire eşittir. }
\end{aligned}
$$

Entropi önteminde karar matrisinde negatif değerler varsa bu durum ağıllıkların hesaplanmasında doğal logaritmadan yararlanıldığ 1 için sorunlara yol açmaktadır. Bunu giderebilmek için negatif değerler pozitif değerlere dönüştürülmelidir.

Zhang, Wang, Li, \& Xu (2014)'nun çalışmasında geliştirilmiş bir entropi ağırlık modeli (Improved Entropy Weight Method) önerilmiştir. Zhang v.d. (2014) yaptıkları çalışmada $Z$-skoru (standart skor) standardizasyon yön- 
temini, maksimum ve maksimumun net olmadığı veya değerin belirli bir aralığı aştığı ayrı veriler için uyarlamışlardır. Çalışmada $Z$-skoru standardizasyon formülü şu şekilde ifade edilmiştir:

$$
x_{i j}=\frac{x_{i j}-\bar{X}_{i}}{S_{i}}
$$

$x_{i j}$ standartlaştırılmış veri; $X_{i j}$ orijinal veri; $\bar{X}_{i}$ ve $S_{i}$ ise sırasıyla endeksin ortalama ve standart sapmasidir.

Endeksler arasında pozitif ve negatif değerlerin çaprazlanmasının neden olduğu indeks oranlarında yanlış hesaplamalardan kaçınmak için, indekslerin bir koordinat dönüştürme yöntemi ile pozitif olması sağlanır. (s.3)

$\dot{x}_{i j}=x_{i j}+A$

$\dot{\chi}_{i j}$ burada dönüşüm sonrası standart değeri ifade etmektedir.

$\mathrm{A}>\left|\min \left(x_{i j}\right)\right|$ olmalıdır.

Endeks ağırlığını belirlemede kullanılan denklem aşağıdaki gibidir:

$p_{i j}=\frac{\dot{x}_{i j}}{\sum_{i=1}^{n} \dot{x}_{i j}}$

$p_{i j}$ her $\dot{x}_{i j}$ için spesifik ağırlık değeridir.

\subsection{TOPSISS Yöntemi}

TOPSIS (technique for order preference by similarity to an ideal solution) yöntemi Chen \& Hwang (1992) tarafindan Hwang \& Yoon (1981) çalışmaları referans alınarak sunulmuştur. ÇKKV yöntemlerinden biri olan TOPSISS yönteminin temel prensibi seçilen alternatifin ideal çözüme en yakın; ideal olmayan çözüme ise en uzak mesafede olmasıdır (Opricovic \& Tzeng, 2004).

TOPSİS yönteminin kullanılmasındaki adımlar şu şekildedir (Chen \& Hwang, 1992):

- Birinci Adım: Normalleştirilmiş karar matrisinin hesaplanması

- İkinci Adım: Normalleştirilmiş ağırlıklandırılmış karar matrisinin hesaplanmas 1

- ÜÇüncü Adım: İdeal ve negatif ideal çözüm değerlerinin belirlenmesi

- Dördüncü Adım: Ayırım ölçülerinin hesaplanması

- Beşinci Adım: İdeal çözüme göreli yakınlığın hesaplanması

- Altıncı adım: Alternatif sıralaması yapmak 


\section{Birinci Adım: Normalleştirilmiş karar matrisinin hesaplanması}

Öncelikle alternatifler ve kriterlere ilgili karar matrisi oluşturulur. Burada $m$ alternatif sayısını $n$ ise kriter sayısını ifade etmektedir.

$m$ adet alternatiften; $n$ adet kriterden oluşan $D$ karar matrisi 6'no'lu eşitlikteki gibi oluşturulur.

$$
\begin{gathered}
D=\left[\begin{array}{cccc}
x_{11} & x_{12} & \cdots & x_{1 n} \\
x_{21} & x_{22} & \cdots & x_{2 n} \\
\vdots & \vdots & \cdots & \vdots \\
x_{m 1} & x_{m 2} & \cdots & x_{m n}
\end{array}\right] \\
i=1,2, \ldots, m \text { ve } j=1,2, \ldots, n
\end{gathered}
$$

Karar matrisinin oluşturulmasının ardından normalleştirme işlemi yapılır. Öncelikle karar matrisindeki her bir sütunda yer alan değerlerinin ayrı ayrı kareleri hesaplanarak toplamı hesaplanır. Bulunan toplamların ayrı ayrı karekökleri hesaplanır. Her bir kriter bulduğumuz bu karekök değerlerine bölünür. (7 No'lu eşitlikteki gibi)

Normalleştirilmiş $r_{i j}$ değeri şu şekilde hesaplanır:

$$
r_{i j}=\frac{x_{i j}}{\sqrt{\sum_{i=1}^{m} x_{i j}^{2}}}, i=1,2, \ldots, m ; j=1,2, \ldots, n .
$$

\section{İkinci Adım: Normalleştirilmiş ağırlıklandırılmış karar matrisinin hesaplanmast}

Normalleştirilmiş karar matrisinin her bir elemanı ilgili kriter ağırlıklarıyla çarpılarak, Normalleştirilmiş ağırlıklandırılmış karar matrisi elde edilir. İlgili kriterlerin ağırlıkları $\left(w_{j}\right)$ objektif ya da sübjektif kriterlere göre belirlenebilir. Bu çalışmada Ağırlıklar Entropi yöntemi kullanılarak objektif kriterlere göre belirlenmiştir.

Normalleştirilmiş ağırlıklandırılmış $v_{i j}$ değeri şu şekilde hesaplanır:

$$
v_{i j}=w_{j} r_{i j}, i=1,2, \ldots, m ; j=1,2, \ldots, n \text {. }
$$

Burada $w_{j}$, j'ninci kriterin ağırlığ

Üçüncü Adım: İdeal ve negatif ideal çözüm değerlerinin belirlenmesi İdeal çözüm (pozitif ideal çözüm) $A^{*}$; negatif ideal çözüm $A^{-}$ise:

$$
\begin{aligned}
& A^{*}=\left\{\left(\max _{i} v_{i j} \mid j \in J\right),\left(\min _{i} v_{i j} \mid j \in J^{\prime}\right) \mid, i=1,2, \ldots, m\right\} \\
& =\left\{v_{1}^{*}, v_{2}^{*}, \ldots, v_{j}^{*}, \ldots, v_{n}^{*}\right\},
\end{aligned}
$$




$$
\begin{aligned}
& A^{-}=\left\{\left(\min _{i} v_{i j} \mid j \in J\right),\left(\max _{i} v_{i j} \mid j \in J^{\prime}\right) \mid, i=1,2, \ldots, m\right\} \\
& =\left\{v_{1}^{-}, v_{2}^{-}, \ldots, v_{j}^{-}, \ldots, v_{n}^{-}\right\}
\end{aligned}
$$

Burada;

$$
\begin{aligned}
& j=\{j=1,2, \ldots, n \mid j \text { fayda kriteri ile ilişkili }\} \\
& j^{\prime}=\{j=1,2, \ldots, n \mid j \text { fayda kriteri ile ilişkili }\}
\end{aligned}
$$

\section{Dördüncü Adım: Aytrım ölçülerinin hesaplanması}

Her alternatif arasındaki ayrım n boyutlu öklid uzaklık ile hesaplanmaktadır. Her alternatifin ideal olandan ayırımı şu şekilde hesaplanır:

İdeal çözümden ayrım: $S_{i}^{*}=\sqrt{\sum_{j=1}^{n}\left(v_{i j}-v_{j}^{*}\right)^{2}}, i=1,2, \ldots$,

Benzer şekilde, negatif ideal çözümden ayrım:

$S_{i}^{-}=\sqrt{\sum_{j=1}^{n}\left(v_{i j}-v_{j}^{-}\right)^{2}}, i=1,2, \ldots, m$.

\section{Beşinci Adım: Ídeal çözüme göreli yakınlı̆̆ın hesaplanması}

$A_{i} \operatorname{nin} A^{*}$ a görece yakınlığı şu şekilde hesaplanır:

$$
C_{i}^{*}=S_{i}^{-} /\left(S_{i}^{*}+S_{i}^{-}\right), 0<C_{i}^{*}<1, i=1,2, \ldots, m .
$$

\section{Altıncı adım: Alternatif sıralamast yapmak}

$C_{i}^{*}$ değerleri büyükten küçüğe sıralanır. En yüksek $C_{i}^{*}$ değerine sahip alternatif en iyi alternatif olarak kabul edilir.

\section{Sayısal Analiz}

\subsection{Entropi Yöntemi ile Ağırlıkların Belirlenmesi}

\section{Birinci Aşama: Karar Matrisinin Oluşturulması}

Eşitlik (1)'den yararlanılarak oluşturulan Borsa İstanbul'da işlem gören 10 mevduat bankasına ait 11 kriterli karar matrisi Tablo 5 'te yer almaktadır: 
Tablo 5: Karar Matrisi

\begin{tabular}{|l|c|c|c|c|c|c|c|c|c|c|c|}
\hline Bankalar/Kriterler & $\mathbf{O 1}$ & $\mathbf{O 2}$ & $\mathbf{O 3}$ & $\mathbf{O 4}$ & $\mathbf{O 5}$ & $\mathbf{O 6}$ & $\mathbf{0 7}$ & $\mathbf{0 8}$ & $\mathbf{0 9}$ & $\mathbf{0 1 0}$ & $\mathbf{0 1 1}$ \\
\hline TVB & 16,993 & 13,750 & 26,532 & 4,647 & 1,380 & 16,100 & 68,134 & 23,139 & 11,249 & 22,242 & 6,501 \\
\hline THL & 13,798 & 10,710 & 22,974 & 3,292 & 0,738 & 9,272 & 71,417 & 27,109 & 10,596 & 17,840 & 1,389 \\
\hline AKB & 18,159 & 15,560 & 15,659 & 4,060 & 1,768 & 13,509 & 78,014 & 18,245 & 14,850 & 29,687 & 4,627 \\
\hline SEK & 15,141 & 11,250 & 33,979 & 5,351 & 0,276 & 3,394 & 84,404 & 39,701 & 11,879 & 21,687 & 0,722 \\
\hline TIB & 16,490 & 13,720 & 18,985 & 4,122 & 1,738 & 14,586 & 88,333 & 22,607 & 11,652 & 22,076 & 1,106 \\
\hline YKB & 16,070 & 12,437 & 27,509 & 5,501 & 1,445 & 13,509 & 75,246 & 18,838 & 16,466 & 31,590 & 0,738 \\
\hline DNZ & 19,487 & 13,570 & 26,744 & 6,353 & 1,687 & 15,447 & 73,035 & 26,668 & 13,138 & 24,561 & 6,128 \\
\hline FIN & 15,423 & 11,660 & 32,629 & 6,067 & 1,701 & 18,033 & 90,035 & 22,550 & 12,607 & 26,180 & 4,482 \\
\hline TGB & 18,308 & 15,840 & 21,417 & 4,860 & 1,939 & 15,084 & 76,284 & 17,798 & 17,470 & 33,406 & 4,382 \\
\hline ICB & 30,810 & 12,090 & 3,287 & 1,191 & 0,437 & 5,602 & 82,646 & 23,171 & 24,676 & 57,190 & 5,508 \\
\hline & MAK & MAK & MIN & MIN & MAK & MAK & MAK & MIN & MAK & MAK & MiN \\
\hline
\end{tabular}

Not: QNB Finansbank A.Ş. (FIN)'nin 11. kriter değeri negatiftir. 11. Kriterin pozitif ya da negatif olarak sıfıra yakın olması tercih edildiği için mutlak değeri alınmıştır.

Karar matrisinin oluşturulmasının ardından, normalleştirilmiş karar matrisi oluşturulmuştur (Tablo 6). Son aşamada ise entropi ağırlık değerleri elde edilmiştir (Tablo 9).

\section{İkinci Aşama: Karar Matrisinin Normalleştirilmesi}

Eşitlik (2) den yararlanılarak normalleştirme işlemi yapılır ve ardından sırası ile Eşitlik (3), Eşitlik (4) ve Eşitlik (5) yardımı ile değerlendirme kriterinin entropi değerleri $\left(e_{j}\right)$; farklılaşma dereceleri $\left(d_{j}\right)$ ve kriterlerin ağırlık dereceleri $\left(w_{j}\right)$ hesaplanır.

Eşitlik (2)'den yararlanarak elde edilen normalleştirilmiş karar matrisi Tablo 6'da yer almaktadır:

Tablo 6: Normalleştirilmiş Karar Matrisi

\begin{tabular}{|l|c|c|c|c|c|c|c|c|c|c|c|}
\hline Bankalar/Kriterler & O1 & O2 & O3 & O4 & O5 & O6 & O7 & O8 & O9 & O10 & O11 \\
\hline TVB & 0,0941 & 0,1053 & 0,1155 & 0,1023 & 0,1053 & 0,1293 & 0,0865 & 0,0965 & 0,0778 & 0,0776 & 0,1827 \\
\hline THL & 0,0764 & 0,0820 & 0,1000 & 0,0724 & 0,0563 & 0,0745 & 0,0907 & 0,1130 & 0,0733 & 0,0623 & 0,0390 \\
\hline AKB & 0,1005 & 0,1192 & 0,0682 & 0,0893 & 0,1348 & 0,1085 & 0,0991 & 0,0761 & 0,1027 & 0,1036 & 0,1300 \\
\hline SEK & 0,0838 & 0,0861 & 0,1479 & 0,1177 & 0,0210 & 0,0273 & 0,1072 & 0,1655 & 0,0822 & 0,0757 & 0,0203 \\
\hline TIB & 0,0913 & 0,1051 & 0,0826 & 0,0907 & 0,1326 & 0,1171 & 0,1122 & 0,0943 & 0,0806 & 0,0771 & 0,0311 \\
\hline YKB & 0,0889 & 0,0952 & 0,1198 & 0,1211 & 0,1102 & 0,1085 & 0,0955 & 0,0785 & 0,1139 & 0,1103 & 0,0208 \\
\hline DNZ & 0,1079 & 0,1039 & 0,1164 & 0,1398 & 0,1287 & 0,1240 & 0,0927 & 0,1112 & 0,0909 & 0,0857 & 0,1722 \\
\hline FIN & 0,0854 & 0,0893 & 0,1420 & 0,1335 & 0,1298 & 0,1448 & 0,1143 & 0,0940 & 0,0872 & 0,0914 & 0,1260 \\
\hline TGB & 0,1013 & 0,1213 & 0,0932 & 0,1070 & 0,1479 & 0,1211 & 0,0969 & 0,0742 & 0,1208 & 0,1166 & 0,1231 \\
\hline ICB & 0,1705 & 0,0926 & 0,0143 & 0,0262 & 0,0333 & 0,0450 & 0,1049 & 0,0966 & 0,1707 & 0,1996 & 0,1548 \\
\hline
\end{tabular}




\section{Üçüncü Aşama: Kriterlere İlişkin Entropi Değerlerinin Bulunması}

Entropi değerleri Eşitlik (3)'den yararlanarak hesaplanır. Hesaplanan entropi değerleri Tablo 7'de yer almıştır.

Tablo 7: Kriterlere İlişkin Entropi Değerlerinin Elde Edilmesi

\begin{tabular}{|l|c|c|c|c|c|c|c|c|c|c|c|}
\hline Bankalar/Kriterler & O1 & $\mathbf{O 2}$ & $\mathbf{O 3}$ & $\mathbf{O 4}$ & $\mathbf{O 5}$ & $\mathbf{O 6}$ & $\mathbf{O 7}$ & $\mathbf{O 8}$ & $\mathbf{O 9}$ & $\mathbf{O 1 0}$ & $\mathbf{0 1 1}$ \\
\hline TVB & $-0,2223$ & $-0,2370$ & $-0,2493$ & $-0,2332$ & $-0,2370$ & $-0,2645$ & $-0,2117$ & $-0,2256$ & $-0,1987$ & $-0,1984$ & $-0,3106$ \\
\hline THL & $-0,1964$ & $-0,2051$ & $-0,2303$ & $-0,1901$ & $-0,1619$ & $-0,1934$ & $-0,2177$ & $-0,2464$ & $-0,1915$ & $-0,1729$ & $-0,1266$ \\
\hline AKB & $-0,2309$ & $-0,2535$ & $-0,1831$ & $-0,2158$ & $-0,2702$ & $-0,2410$ & $-0,2290$ & $-0,1960$ & $-0,2338$ & $-0,2349$ & $-0,2653$ \\
\hline SEK & $-0,2078$ & $-0,2112$ & $-0,2827$ & $-0,2519$ & $-0,0812$ & $-0,0982$ & $-0,2394$ & $-0,2977$ & $-0,2053$ & $-0,1954$ & $-0,0791$ \\
\hline TIB & $-0,2185$ & $-0,2367$ & $-0,2061$ & $-0,2177$ & $-0,2679$ & $-0,2512$ & $-0,2454$ & $-0,2226$ & $-0,2030$ & $-0,1975$ & $-0,1079$ \\
\hline YKB & $-0,2152$ & $-0,2239$ & $-0,2542$ & $-0,2556$ & $-0,2431$ & $-0,2409$ & $-0,2244$ & $-0,1998$ & $-0,2474$ & $-0,2431$ & $-0,0804$ \\
\hline DNZ & $-0,2402$ & $-0,2353$ & $-0,2504$ & $-0,2751$ & $-0,2639$ & $-0,2589$ & $-0,2205$ & $-0,2442$ & $-0,2179$ & $-0,2106$ & $-0,3029$ \\
\hline FIN & $-0,2101$ & $-0,2157$ & $-0,2772$ & $-0,2688$ & $-0,2650$ & $-0,2798$ & $-0,2479$ & $-0,2223$ & $-0,2127$ & $-0,2187$ & $-0,2610$ \\
\hline TGB & $-0,2320$ & $-0,2559$ & $-0,2212$ & $-0,2391$ & $-0,2827$ & $-0,2557$ & $-0,2261$ & $-0,1930$ & $-0,2554$ & $-0,2506$ & $-0,2579$ \\
\hline ICB & $-0,3016$ & $-0,2203$ & $-0,0608$ & $-0,0954$ & $-0,1134$ & $-0,1395$ & $-0,2366$ & $-0,2258$ & $-0,3017$ & $-0,3217$ & $-0,2888$ \\
\hline
\end{tabular}

Dördüncü Aşama: Farklılaşma Derecelerinin Bulunması

$d_{j}$ değerleri her bir kriter için daha önce bulunan entropi değerleri kullanılarak Eşitlik (4)'ten yararlanılarak bulunur.

Tablo 8: Farklılaşma Derecelerinin Bulunması

\begin{tabular}{|c|c|c|c|c|c|c|c|c|c|c|c|}
\hline $\mathrm{e}_{\mathrm{j}}$ & 0,9880 & 0,9966 & 0,9620 & 0,9740 & 0,9495 & 0,9654 & 0,9983 & 0,9874 & 0,9847 & 0,9745 & 0,9035 \\
\hline $\mathrm{d}_{\mathrm{i}}$ & 0,0120 & 0,0034 & 0,0380 & 0,0260 & 0,0505 & 0,0346 & 0,0017 & 0,0126 & 0,0153 & 0,0255 & 0,0965 \\
\hline$\sum \mathrm{d}_{\mathrm{j}}$ & 0,3161 & & & & & & & & & & \\
\hline
\end{tabular}

Beşinci Aşama: Entropi Kriter Ağırlıklarının Hesaplanması

Eşitlik (5)'den yararlanarak bulunan entropi kriter ağırlıkları Tablo 9'da yer almaktadır:

Tablo 9: Entropi Kriter A ̆̆ırlıklarının Hesaplanması

\begin{tabular}{|c|c|c|c|c|c|c|c|c|c|c|c|}
\hline & O1 & O2 & O3 & O4 & O5 & O6 & O7 & O8 & O9 & O10 & O11 \\
\hline $\mathrm{w}_{\mathrm{j}}$ & 0,0379 & 0,0109 & 0,1202 & 0,0823 & 0,1599 & 0,1093 & 0,0053 & 0,0399 & 0,0483 & 0,0807 & 0,3053 \\
\hline
\end{tabular}

Uygulama sonuçlarına göre en önemli kriter O11 $(0,3053)$ olarak belirlenmiştir. 


\subsection{Topsis Yöntemi ile Sıralama Yapılması}

\section{Birinci Adım: Normalleştirilmiş karar matrisinin hesaplanması:}

i.) Karar matrisinin oluşturulması

Borsa İstanbul'da işlem gören mevduat bankalarının finansal sağlamlıklarını değerlendirebilmek için 11 kriter saptanmıştır. Bu kriterler, alternatifler ve değerlerin yer aldığı karar matrisi Tablo 10'da yer almaktadır.

\section{Tablo 10: Karar Matrisi}

\begin{tabular}{|l|c|c|c|c|c|c|c|c|c|c|c|}
\hline Bankalar/Kriterler & O1 & O2 & O3 & O4 & O5 & O6 & O7 & O8 & O9 & O10 & O11 \\
\hline TVB & 17,0 & 13,8 & 26,5 & 4,6 & 1,4 & 16,1 & 68,1 & 23,1 & 11,2 & 22,2 & 6,5 \\
\hline THL & 13,8 & 10,7 & 23,0 & 3,3 & 0,7 & 9,3 & 71,4 & 27,1 & 10,6 & 17,8 & 1,4 \\
\hline AKB & 18,2 & 15,6 & 15,7 & 4,1 & 1,8 & 13,5 & 78,0 & 18,2 & 14,9 & 29,7 & 4,6 \\
\hline SEK & 15,1 & 11,3 & 34,0 & 5,4 & 0,3 & 3,4 & 84,4 & 39,7 & 11,9 & 21,7 & 0,7 \\
\hline TIB & 16,5 & 13,7 & 19,0 & 4,1 & 1,7 & 14,6 & 88,3 & 22,6 & 11,7 & 22,1 & 1,1 \\
\hline YKB & 16,1 & 12,4 & 27,5 & 5,5 & 1,4 & 13,5 & 75,2 & 18,8 & 16,5 & 31,6 & 0,7 \\
\hline DNZ & 19,5 & 13,6 & 26,7 & 6,4 & 1,7 & 15,4 & 73,0 & 26,7 & 13,1 & 24,6 & 6,1 \\
\hline FIN & 15,4 & 11,7 & 32,6 & 6,1 & 1,7 & 18,0 & 90,0 & 22,6 & 12,6 & 26,2 & $-4,5$ \\
\hline TGB & 18,3 & 15,8 & 21,4 & 4,9 & 1,9 & 15,1 & 76,3 & 17,8 & 17,5 & 33,4 & 4,4 \\
\hline ICB & 30,8 & 12,1 & 3,3 & 1,2 & 0,4 & 5,6 & 82,6 & 23,2 & 24,7 & 57,2 & 5,5 \\
\hline & max & $\max$ & $\min$ & $\min$ & $\max$ & $\max$ & $\max$ & $\min$ & $\max$ & $\max$ & $\min$ \\
\hline
\end{tabular}

ii.) Normalleştirilmiş Karar Matrisin Elde Edilmesi

Karar matrisinin normalleştirilmesi edilmesi için öncelikle her alternatife ait her bir değerin karesi alınır. Karesi alınan değerlerin sütun toplamı bulunur. Bulunan sonuçların da her bir kriter için karekökü hesaplanır. Bu aşamadan sonra ise her bir değer, sonuçların karelerinin toplamının kareköküne bölünerek normalleştirilmiş standart karar matrisi elde edilir (Tablo 11).

\begin{tabular}{|l|c|c|c|c|c|c|c|c|c|c|c|}
\hline & O1 & O2 & O3 & O4 & O5 & O6 & O7 & O8 & O9 & O10 & O11 \\
\hline $\begin{array}{l}\text { Sütunların karelerinin } \\
\text { toplamının karekökü }\end{array}$ & 58,91 & 41,62 & 77,45 & 15,07 & 4,52 & 41,92 & 250,02 & 78,22 & 47,47 & 96,57 & 13,23 \\
\hline
\end{tabular}

Tablo 11: Normallleştirilmiş Karar Matrisi

\begin{tabular}{|l|c|c|c|c|c|c|c|c|c|c|c|}
\hline $\begin{array}{l}\text { Bankalar/ } \\
\text { Kriterler }\end{array}$ & O1 & O2 & O3 & O4 & O5 & O6 & O7 & O8 & O9 & O10 & O11 \\
\hline TVB & 0,28847 & 0,33034 & 0,34258 & 0,30843 & 0,30521 & 0,38407 & 0,27252 & 0,29581 & 0,23698 & 0,23032 & 0,49132 \\
\hline THL & 0,23422 & 0,25731 & 0,29664 & 0,21847 & 0,16309 & 0,22119 & 0,28565 & 0,34656 & 0,22324 & 0,18475 & 0,10495 \\
\hline AKB & 0,30825 & 0,37383 & 0,20219 & 0,26947 & 0,39089 & 0,32228 & 0,31204 & 0,23324 & 0,31286 & 0,30742 & 0,34968 \\
\hline SEK & 0,25702 & 0,27028 & 0,43873 & 0,35512 & 0,06094 & 0,08096 & 0,33760 & 0,50755 & 0,25027 & 0,22458 & 0,05457 \\
\hline TIB & 0,27991 & 0,32962 & 0,24513 & 0,27358 & 0,38439 & 0,34797 & 0,35331 & 0,28901 & 0,24549 & 0,22861 & 0,08362 \\
\hline
\end{tabular}




\begin{tabular}{|l|l|l|l|l|l|l|l|l|l|l|l|}
\hline YKB & 0,27279 & 0,29880 & 0,35520 & 0,36513 & 0,31958 & 0,32227 & 0,30097 & 0,24082 & 0,34691 & 0,32713 & 0,05581 \\
\hline DNZ & 0,33079 & 0,32602 & 0,34532 & 0,42165 & 0,37307 & 0,36851 & 0,29212 & 0,34092 & 0,27679 & 0,25435 & 0,46313 \\
\hline FIN & 0,26180 & 0,28013 & 0,42131 & 0,40269 & 0,37620 & 0,43019 & 0,36012 & 0,28829 & 0,26560 & 0,27111 & $-0,33874$ \\
\hline TGB & 0,31078 & 0,38055 & 0,27653 & 0,32259 & 0,42873 & 0,35984 & 0,30512 & 0,22754 & 0,36806 & 0,34594 & 0,33118 \\
\hline ICB & 0,52301 & 0,29046 & 0,04244 & 0,07904 & 0,09662 & 0,13363 & 0,33057 & 0,29622 & 0,51986 & 0,59223 & 0,41631 \\
\hline
\end{tabular}

İkinci Adım: Normalleştirilmiş ağırlıklandırılmış karar matrisinin hesaplanmast

Her kriter için Entropi Yöntemi ile hesaplanan ağırlıklar (w) Tablo 12 'de yer almaktadır.

Tablo 12: Kriterlerin Ağırlıkları ve Yönü

\begin{tabular}{|l|c|c|c|c|c|c|c|c|c|c|c|}
\hline Kriterler & O1 & O2 & O3 & O4 & O5 & O6 & O7 & O8 & O9 & O10 & O11 \\
\hline $\begin{array}{l}\text { Ağırlıklar } \\
(w)\end{array}$ & 0,0379 & 0,0109 & 0,1202 & 0,0823 & 0,1599 & 0,1093 & 0,0053 & 0,0399 & 0,0483 & 0,0807 & 0,3053 \\
\hline $\begin{array}{l}\text { Kriterin } \\
\text { Yönü }\end{array}$ & $\max$ & $\max$ & $\min$ & $\min$ & $\max$ & $\max$ & $\max$ & $\min$ & $\max$ & $\max$ & $\min$ \\
\hline
\end{tabular}

Tablo 11'deki Normalleştirilmiş karar matrisinde yer alan her bir değer, Tablo 12'de yer alan kriter ağırlıklarıyla çarpılmak suretiyle normalleştirilmiş ağırlıklandırılmış karar matrisi elde edilmiştir (Tablo 13).

Tablo 13: Normalleştirilmiş Ağırlıklandırılmış Karar Matrisi

\begin{tabular}{|l|c|c|c|c|c|c|c|c|c|c|c|}
\hline Bankalar/Kriterler & O1 & O2 & O3 & O4 & O5 & O6 & O7 & O8 & O9 & O10 & O11 \\
\hline TVB & 0,01093 & 0,00359 & 0,04118 & 0,02538 & 0,04880 & 0,04199 & 0,00146 & 0,01181 & 0,01145 & 0,01859 & 0,14998 \\
\hline THL & 0,00887 & 0,00280 & 0,03566 & 0,01798 & 0,02608 & 0,02418 & 0,00153 & 0,01384 & 0,01079 & 0,01491 & 0,03204 \\
\hline AKB & 0,01168 & 0,00406 & 0,02430 & 0,02217 & 0,06250 & 0,03524 & 0,00167 & 0,00931 & 0,01512 & 0,02481 & 0,10675 \\
\hline SEK & 0,00974 & 0,00294 & 0,05273 & 0,02922 & 0,00974 & 0,00885 & 0,00180 & 0,02026 & 0,01209 & 0,01813 & 0,01666 \\
\hline TIB & 0,01060 & 0,00358 & 0,02946 & 0,02251 & 0,06146 & 0,03805 & 0,00189 & 0,01154 & 0,01186 & 0,01845 & 0,02553 \\
\hline YKB & 0,01033 & 0,00325 & 0,04269 & 0,03004 & 0,05110 & 0,03524 & 0,00161 & 0,00961 & 0,01676 & 0,02640 & 0,01704 \\
\hline DNZ & 0,01253 & 0,00354 & 0,04151 & 0,03469 & 0,05965 & 0,04029 & 0,00156 & 0,01361 & 0,01337 & 0,02053 & 0,14138 \\
\hline FIN & 0,00992 & 0,00305 & 0,05064 & 0,03313 & 0,06015 & 0,04703 & 0,00192 & 0,01151 & 0,01283 & 0,02188 & $-0,10340$ \\
\hline TGB & 0,01177 & 0,00414 & 0,03324 & 0,02654 & 0,06855 & 0,03934 & 0,00163 & 0,00908 & 0,01778 & 0,02792 & 0,10110 \\
\hline ICB & 0,01981 & 0,00316 & 0,00510 & 0,00650 & 0,01545 & 0,01461 & 0,00177 & 0,01183 & 0,02512 & 0,04780 & 0,12708 \\
\hline
\end{tabular}

Üçüncü Adım: İdeal ( $\left.A^{*}\right)$ ve negatif ideal $\left(A^{-}\right)$çözüm değerlerinin belirlenmesi

Ağırlıklandırılmış karar matrisindeki her bir sütun için maksimum ve minimum değerler bulunur. 


\begin{tabular}{|c|c|c|c|c|c|c|c|c|c|c|c|}
\hline & MAK & MAK & MIN & MIN & MAK & MAK & MAK & MIN & MAK & MAK & MIN \\
\hline \multicolumn{12}{|c|}{ pozitif ve negatif ideal çözüm değerleri } \\
\hline \multicolumn{12}{|c|}{ 4.aşama pozitif ideal $\left(\mathrm{A}^{*}\right)$ ve negatif ideal $\left(\mathrm{A}^{-}\right)$çözüm değerlerinin belirlenmesi } \\
\hline $\begin{array}{l}\text { pozitif } \\
\text { ideal } \\
\text { çözüm }\end{array}$ & 0,019810 & 0,004138 & 0,005101 & 0,006504 & 0,068546 & 0,047035 & 0,001925 & 0,009084 & 0,025116 & 0,047801 & $-0,103405$ \\
\hline $\begin{array}{l}\text { negatif } \\
\text { ideal } \\
\text { çözüm }\end{array}$ & 0,008872 & 0,002798 & 0,052734 & 0,034692 & 0,009743 & 0,008852 & 0,001456 & 0,020262 & 0,010785 & 0,014912 & 0,149982 \\
\hline
\end{tabular}

\section{Dördüncü Adım: Ayırım ölçülerinin hesaplanması}

Pozitif ideal noktalara olan uzaklığın hesaplanmasında ağırlıklandırılmış karar matrisi ve pozitif ideal çözüm değerleri; negatif ideal noktalara olan uzaklığın hesaplanmasında ise ağırlıklandırılmış karar matrisi ve negatif ideal çözüm değerleri kullanılır.

\begin{tabular}{|c|c|c|c|c|c|c|c|c|c|c|c|c|c|}
\hline \multirow[b]{2}{*}{$\begin{array}{l}\text { Bankalar / } \\
\text { Kriterler }\end{array}$} & \multicolumn{5}{|c|}{ pozitif ideal uzaklığın hesaplanması } & \multirow[b]{2}{*}{06} & \multirow[b]{2}{*}{07} & \multirow[b]{2}{*}{ O8 } & \multirow[b]{2}{*}{ O9 } & \multirow[b]{2}{*}{010} & \multirow[b]{2}{*}{011} & \multirow[b]{2}{*}{ toplam } & \multirow[b]{2}{*}{$\mathrm{Si}^{*}$} \\
\hline & 01 & O2 & O3 & O4 & 05 & & & & & & & & \\
\hline TVB & $7,892 \mathrm{E}-05$ & $2,981 \mathrm{E}-07$ & $1,301 \mathrm{E}-03$ & $3,562 \mathrm{E}-04$ & $3,900 \mathrm{E}-04$ & $2,542 \mathrm{E}-05$ & $2,192 \mathrm{E}-07$ & $7,429 \mathrm{E}-06$ & $1,868 \mathrm{E}-04$ & $8,533 \mathrm{E}-04$ & $6,421 \mathrm{E}-02$ & $6,741 \mathrm{E}-02$ & 2,596E-01 \\
\hline THL & $1,196 \mathrm{E}-04$ & $1,796 \mathrm{E}-06$ & $9,335 \mathrm{E}-04$ & $1,316 \mathrm{E}-04$ & $1,804 \mathrm{E}-03$ & $5,222 \mathrm{E}-04$ & $1,584 \mathrm{E}-07$ & $2,258 \mathrm{E}-05$ & $2,054 \mathrm{E}-04$ & $1,082 \mathrm{E}-03$ & $1,834 \mathrm{E}-02$ & 2,317E-02 & $1,522 \mathrm{E}-01$ \\
\hline AKB & $6,617 \mathrm{E}-05$ & $5,350 \mathrm{E}-09$ & $3,687 \mathrm{E}-04$ & $2,455 \mathrm{E}-04$ & $3,660 \mathrm{E}-05$ & $1,392 \mathrm{E}-04$ & $6,603 \mathrm{E}-08$ & $5,188 \mathrm{E}-08$ & $1,000 \mathrm{E}-04$ & $5,284 \mathrm{E}-04$ & $4,416 \mathrm{E}-02$ & $4,565 \mathrm{E}-02$ & 2,137E-01 \\
\hline SEK & $1,015 \mathrm{E}-04$ & $1,438 \mathrm{E}-06$ & $2,269 \mathrm{E}-03$ & $5,160 \mathrm{E}-04$ & $3,458 \mathrm{E}-03$ & $1,458 \mathrm{E}-03$ & $1,449 \mathrm{E}-08$ & $1,250 \mathrm{E}-04$ & $1,696 \mathrm{E}-04$ & $8,806 \mathrm{E}-04$ & $1,441 \mathrm{E}-02$ & 2,339E-02 & 1,529E-01 \\
\hline TIB & $8,478 \mathrm{E}-05$ & $3,067 \mathrm{E}-07$ & 5,935E-04 & $2,562 \mathrm{E}-04$ & $5,025 \mathrm{E}-05$ & $8,080 \mathrm{E}-05$ & 1,324E-09 & $6,024 \mathrm{E}-06$ & $1,757 \mathrm{E}-04$ & $8,614 \mathrm{E}-04$ & $1,662 \mathrm{E}-02$ & $1,873 \mathrm{E}-02$ & 1,369E-01 \\
\hline YKB & $8,982 \mathrm{E}-05$ & $7,902 \mathrm{E}-07$ & $1,413 \mathrm{E}-03$ & $5,541 \mathrm{E}-04$ & $3,045 \mathrm{E}-04$ & $1,392 \mathrm{E}-04$ & $9,994 \mathrm{E}-08$ & $2,814 \mathrm{E}-07$ & $6,982 \mathrm{E}-05$ & $4,578 \mathrm{E}-04$ & $1,451 \mathrm{E}-02$ & $1,754 \mathrm{E}-02$ & 1,324E-01 \\
\hline DNZ & $5,301 \mathrm{E}-05$ & $3,516 \mathrm{E}-07$ & $1,325 \mathrm{E}-03$ & 7,946E-04 & 7,919E-05 & 4,547E-05 & $1,321 \mathrm{E}-07$ & $2,049 \mathrm{E}-05$ & $1,379 \mathrm{E}-04$ & 7,437E-04 & $5,992 \mathrm{E}-02$ & 6,312E-02 & 2,512E-01 \\
\hline FIN & $9,788 \mathrm{E}-05$ & $1,192 \mathrm{E}-06$ & $2,074 \mathrm{E}-03$ & 7,091E-04 & $7,054 \mathrm{E}-05$ & $0,000 \mathrm{E}+00$ & $0,000 \mathrm{E}+00$ & $5,882 \mathrm{E}-06$ & $1,509 \mathrm{E}-04$ & $6,718 \mathrm{E}-04$ & $0,000 \mathrm{E}+00$ & $3,781 \mathrm{E}-03$ & 6,149E-02 \\
\hline TGB & $6,462 \mathrm{E}-05$ & $0,000 \mathrm{E}+00$ & 7,917E-04 & $4,015 \mathrm{E}-04$ & $0,000 \mathrm{E}+00$ & $5,917 \mathrm{E}-05$ & 8,640 E- 08 & $0,000 \mathrm{E}+00$ & $5,379 \mathrm{E}-05$ & $3,952 \mathrm{E}-04$ & $4,182 \mathrm{E}-02$ & 4,359E-02 & 2,088E-01 \\
\hline ICB & $0,000 \mathrm{E}+00$ & $9,596 \mathrm{E}-07$ & $0,000 \mathrm{E}+00$ & $0,000 \mathrm{E}+00$ & 2,819E-03 & $1,051 \mathrm{E}-03$ & $2,495 \mathrm{E}-08$ & $7,519 \mathrm{E}-06$ & $0,000 \mathrm{E}+00$ & $0,000 \mathrm{E}+00$ & $5,313 \mathrm{E}-02$ & $5,700 \mathrm{E}-02$ & 2,388E-01 \\
\hline
\end{tabular}

\begin{tabular}{|c|c|c|c|c|c|c|c|c|c|c|c|c|c|}
\hline \multirow[b]{2}{*}{$\begin{array}{l}\text { Bankalar } \\
\text { / Kriterler }\end{array}$} & \multicolumn{5}{|c|}{ negatif ideal uzaklığın hesaplanması } & \multirow[b]{2}{*}{ O6 } & \multirow[b]{2}{*}{07} & \multirow[b]{2}{*}{08} & \multirow[b]{2}{*}{09} & \multirow[b]{2}{*}{010} & \multirow[b]{2}{*}{011} & \multirow[b]{2}{*}{ toplam } & \multirow[b]{2}{*}{$\mathrm{S}_{\mathrm{i}}^{-}$} \\
\hline & 01 & $\mathbf{O 2}$ & $\mathbf{O 3}$ & 04 & 05 & & & & & & & & \\
\hline TVB & $4,221 \mathrm{E}-06$ & $6,306 \mathrm{E}-07$ & $1,336 \mathrm{E}-04$ & $8,677 \mathrm{E}-05$ & $1,525 \mathrm{E}-03$ & $1,098 \mathrm{E}-03$ & $0,000 \mathrm{E}+00$ & $7,145 \mathrm{E}-05$ & $4,413 \mathrm{E}-07$ & $1,353 \mathrm{E}-05$ & $0,000 \mathrm{E}+00$ & $2,934 \mathrm{E}-03$ & $5,417 \mathrm{E}-02$ \\
\hline THL & $0,000 \mathrm{E}+00$ & $0,000 \mathrm{E}+00$ & 2,917E-04 & 2,795E-04 & $2,668 \mathrm{E}-04$ & $2,351 \mathrm{E}-04$ & $4,923 \mathrm{E}-09$ & $4,131 \mathrm{E}-05$ & $0,000 \mathrm{E}+00$ & $0,000 \mathrm{E}+00$ & $1,391 \mathrm{E}-02$ & $1,503 \mathrm{E}-02$ & $1,226 \mathrm{E}-01$ \\
\hline AKB & $7,861 \mathrm{E}-06$ & $1,605 \mathrm{E}-06$ & $8,084 \mathrm{E}-04$ & $1,568 \mathrm{E}-04$ & $2,783 \mathrm{E}-03$ & 6,962E-04 & $4,461 \mathrm{E}-08$ & $1,199 \mathrm{E}-04$ & $1,875 \mathrm{E}-05$ & $9,804 \mathrm{E}-05$ & $1,869 \mathrm{E}-03$ & $6,560 \mathrm{E}-03$ & $8,099 \mathrm{E}-02$ \\
\hline SEK & $7,458 \mathrm{E}-07$ & $1,990 \mathrm{E}-08$ & $0,000 \mathrm{E}+00$ & $2,996 \mathrm{E}-05$ & $0,000 \mathrm{E}+00$ & $0,000 \mathrm{E}+00$ & $1,210 \mathrm{E}-07$ & $0,000 \mathrm{E}+00$ & $1,707 \mathrm{E}-06$ & $1,034 \mathrm{E}-05$ & $1,778 \mathrm{E}-02$ & $1,782 \mathrm{E}-02$ & $1,335 \mathrm{E}-01$ \\
\hline TIB & $2,995 \mathrm{E}-06$ & $6,182 \mathrm{E}-07$ & $5,415 \mathrm{E}-04$ & $1,484 \mathrm{E}-04$ & $2,674 \mathrm{E}-03$ & $8,523 \mathrm{E}-04$ & $1,864 \mathrm{E}-07$ & 7,611E-05 & $1,156 \mathrm{E}-06$ & $1,253 \mathrm{E}-05$ & $1,549 \mathrm{E}-02$ & $1,980 \mathrm{E}-02$ & $1,407 \mathrm{E}-01$ \\
\hline YKB & $2,134 \mathrm{E}-06$ & $2,035 \mathrm{E}-07$ & $1,008 \mathrm{E}-04$ & $2,162 \mathrm{E}-05$ & $1,710 \mathrm{E}-03$ & $6,961 \mathrm{E}-04$ & 2,311E-08 & $1,134 \mathrm{E}-04$ & $3,570 \mathrm{E}-05$ & $1,321 \mathrm{E}-04$ & $1,767 \mathrm{E}-02$ & $2,049 \mathrm{E}-02$ & $1,431 \mathrm{E}-01$ \\
\hline DNZ & $1,338 \mathrm{E}-05$ & $5,581 \mathrm{E}-07$ & $1,261 \mathrm{E}-04$ & $0,000 \mathrm{E}+00$ & $2,490 \mathrm{E}-03$ & $9,885 \mathrm{E}-04$ & $1,097 \mathrm{E}-08$ & $4,425 \mathrm{E}-05$ & $6,694 \mathrm{E}-06$ & $3,156 \mathrm{E}-05$ & 7,407E-05 & $3,775 \mathrm{E}-03$ & $6,144 \mathrm{E}-02$ \\
\hline FIN & $1,091 \mathrm{E}-06$ & $6,158 \mathrm{E}-08$ & $4,388 \mathrm{E}-06$ & $2,433 \mathrm{E}-06$ & $2,541 \mathrm{E}-03$ & $1,458 \mathrm{E}-03$ & $2,192 \mathrm{E}-07$ & $7,662 \mathrm{E}-05$ & $4,190 \mathrm{E}-06$ & $4,859 \mathrm{E}-05$ & $6,421 \mathrm{E}-02$ & $6,834 \mathrm{E}-02$ & $2,614 \mathrm{E}-01$ \\
\hline TGB & $8,409 \mathrm{E}-06$ & $1,796 \mathrm{E}-06$ & $3,801 \mathrm{E}-04$ & $6,643 \mathrm{E}-05$ & $3,458 \mathrm{E}-03$ & $9,297 \mathrm{E}-04$ & $3,035 \mathrm{E}-08$ & $1,250 \mathrm{E}-04$ & $4,896 \mathrm{E}-05$ & $1,693 \mathrm{E}-04$ & $2,390 \mathrm{E}-03$ & 7,577E- 03 & $8,705 \mathrm{E}-02$ \\
\hline ICB & $1,196 \mathrm{E}-04$ & $1,299 \mathrm{E}-07$ & $2,269 \mathrm{E}-03$ & 7,946E-04 & $3,255 \mathrm{E}-05$ & $3,317 \mathrm{E}-05$ & $9,624 \mathrm{E}-08$ & 7,117E-05 & 2,054E-04 & $1,082 \mathrm{E}-03$ & $5,243 \mathrm{E}-04$ & $5,132 \mathrm{E}-03$ & $7,164 \mathrm{E}-02$ \\
\hline
\end{tabular}


Beşinci Adım: İdeal çözüme göreli yakınlığın hesaplanması

\begin{tabular}{|l|c|c|}
\hline Banka & $\mathbf{C}_{\mathbf{i}}{ }^{*}$ & Siralamalar \\
\hline TVB & 0,172623288 & 10 \\
\hline THL & 0,446086493 & 5 \\
\hline AKB & 0,274882942 & 7 \\
\hline SEK & 0,46602464 & 4 \\
\hline TIB & 0,506927193 & 3 \\
\hline YKB & 0,519427554 & 2 \\
\hline DNZ & 0,196511695 & 9 \\
\hline FIN & 0,809576633 & 1 \\
\hline TGB & 0,294254124 & 6 \\
\hline ICB & 0,230791022 & 8 \\
\hline
\end{tabular}

$\mathrm{Ci}^{*}$ değerleri her bir banka alternatifinin pozitif ideal çözüme göreli yakınlığını göstermektedir. Ci* değerleri hesaplanmış ve rank formülüyle bu değerler büyükten küçüğe sıralanmıştır. En yüksek $\mathrm{Ci}^{*}$ değerine sahip banka 1. sıradaki QNB Finansbank A.Ş. en iyi alternatif olarak belirlenmiştir.

Altıncı adım: Alternatif sıralamast yapmak

\section{Sıralı sonuç tablosu}

\begin{tabular}{|l|c|c|}
\hline Banka & $\mathbf{C i}^{*}$ & SIralamalar \\
\hline FIN & 0,809576633 & 1 \\
\hline YKB & 0,519427554 & 2 \\
\hline TIB & 0,506927193 & 3 \\
\hline SEK & 0,46602464 & 4 \\
\hline THL & 0,446086493 & 5 \\
\hline TGB & 0,294254124 & 6 \\
\hline AKB & 0,274882942 & 7 \\
\hline ICB & 0,230791022 & 8 \\
\hline DNZ & 0,196511695 & 9 \\
\hline TVB & 0,172623288 & 10 \\
\hline
\end{tabular}

\section{Genel Değerlendirme ve Sonuç}

IMF finansal sağlamlık göstergeleri kullanılarak ve ÇKKV yöntemleri uygulanarak yapılan çalışmalar ağırlıklı olarak ülkelerin bankacılık sistemlerini karşılaştırmaya ve sektörlerin finansal performanslarını değerlendirmeye odaklanmıştır. Bu çalışmada ise IMF finansal sağlamlık göstergeleri baz alınarak, belirlenen kriterlere göre TOPSİS yöntemi kullanılarak, seçilmiş mevduat bankalarının finansal sağlamlık açısından karşılaştırılması amaçlanmıştır. Araştırmada kriterlerin ağırlıkları subjektif olarak hesaplanmak yerine, 
ağırlıkların objektif olarak saptanmasında tercih edilen yöntemlerden biri olan Entropi yöntemi kullanılmıştır.

Borsa İstanbul'da işlem gören mevduat bankalarının IMF finansal sağlamlık göstergeleri açısından değerlendirildiği çalışmada 11 adet finansal sağlamlık göstergesinden yararlanılmıştır. Bankaların 2018 yılına ilişkin verileri kullanılarak ÇKKV yöntemlerinden Entropi yöntemi ile kriterlerin ağırlıkları saptanmış; ardından TOPSIS yönteminden yararlanılarak Borsa İstanbul'da işlem gören mevduat bankalarının 2018 yılına ilişkin finansal sağlamlıklarına yönelik bir sıralama oluşturulmuştur.

\begin{tabular}{|l|l|l|l|l|}
\hline Siralamalar & Banka & $\mathbf{C}_{\mathbf{i}}{ }^{*}$ & $\mathbf{S}_{\mathbf{i}}^{-}$ & $\mathbf{S i}^{*}$ \\
\hline 1 & FIN & 0,809577 & $2,61 \mathrm{E}-01$ & $6,15 \mathrm{E}-02$ \\
\hline 2 & YKB & 0,519428 & $1,43 \mathrm{E}-01$ & $1,32 \mathrm{E}-01$ \\
\hline 3 & TIB & 0,506927 & $1,41 \mathrm{E}-01$ & $1,37 \mathrm{E}-01$ \\
\hline 4 & SEK & 0,466025 & $1,34 \mathrm{E}-01$ & $1,53 \mathrm{E}-01$ \\
\hline 5 & THL & 0,446086 & $1,23 \mathrm{E}-01$ & $1,52 \mathrm{E}-01$ \\
\hline 6 & TGB & 0,294254 & $8,71 \mathrm{E}-02$ & $2,09 \mathrm{E}-01$ \\
\hline 7 & AKB & 0,274883 & $8,10 \mathrm{E}-02$ & $2,14 \mathrm{E}-01$ \\
\hline 8 & ICB & 0,230791 & $7,16 \mathrm{E}-02$ & $2,39 \mathrm{E}-01$ \\
\hline 9 & DNZ & 0,196512 & $6,14 \mathrm{E}-02$ & $2,51 \mathrm{E}-01$ \\
\hline 10 & TVB & 0,172623 & $5,42 \mathrm{E}-02$ & $2,60 \mathrm{E}-01$ \\
\hline
\end{tabular}

Finansal sağlamlık sıralaması açısından ilk sırayı en yüksek $\mathrm{C} i *$ değerine sahip olan QNB Finansbank A.Ş. almaktadır. İkinci sırada Yapı ve Kredi Bankası A.Ş. yer almaktadır. Üçüncü sırada Türkiye İş Bankası A.Ş. yer almıştır. Kamu sermayeli bankalardan Türkiye Halk Bankası A.Ş. 5. Sırada yer alırken; Türkiye Vakıflar Bankası T.A.O. ise 10. sırada yer almıştır. 


\section{Kaynakça}

Akgül, Y. (2019). Çok Kriterli Karar Verme Yöntemleriyle Türk Bankacılık sisteminin 20102018 Yılları Arasındaki Performansının Analizi. Finans Ekonomi ve Sosyal Araştırmalar Dergisi. 4 (4). 567-582. DOI: 10.29106/fesa.655722. (Erişim Tarihi: 29.02.2020).

Aldemir, A. \& Özden Ü. H. (2017). Türkiye'deki Mevduat Bankalarının Çok Kriterli Karar Verme Yöntemi İle Analizi. Avrasya İşletme ve İktisat Dergisi Yı1:2017. Sayı: 12. (Erişim Tarihi: 16.10.2019).

Ayçin, E., (2019). Çok Kriterli Karar Verme: Bilgisayar Uygulamalı Çözümler. Nobel Yayınevi. Ankara.

Ayçin, E. \& Orçun, Ç. (2019). Mevduat Bankalarının Performanslarının Entropi ve Mairca Yöntemleri İle Değerlendirilmesi. Balıkesir Üniversitesi Sosyal Bilimler Enstitüsü Dergisi. 22 (42). 175-194. DOI: 10.31795/baunsobed.657002. (Erişim Tarihi: 29.02.2020).

BDDK (2019). Türk Bankacılık Sektörü Temel Göstergeleri Aralık 2018. https://www.bddk. org.tr/ContentBddk/dokuman/veri_0014_39.pdf. (Erişim tarihi: 25.02.2020).

Borsa İstanbul (2019). Üye Bilgileri, https://www.borsaistanbul.com/borsa_uyeleri/uyebilgileri?g=3\&y=205. (Erişim Tarihi: 28.10 .2019$)$.

Chen, S. J. \& Hwang, C. L. (1992). Fuzzy Multiple Attribute Decision Making: Methods and Applications. Springer-Verlagç Berlin. Ss.38-39.

Demireli, E. (2010). Topsis Çok Kriterli Karar Verme Sistemi: Türkiye’deki Kamu Bankalar1 Üzerine Bir Uygulama. Girişimcilik ve Kalkınma Dergisi (5:1) 2010. (Erişim Tarihi: 16.10.2019).

Eyüboğlu, K. (2016). Gelişmekte Olan Ülkelerin Bankacılık Finansal Sektör Finansal Performanslarının Topsis Yöntemi İle Karşılaştırılması. Odtü Sosyal Bilimler Araştırmaları Dergisi (ODÜSOBİAD). 6 (14). 220-236. https://dergipark.org.tr/tr/pub/odusobiad/issue/27560/289969. (Erişim Tarihi: 27.10.2019).

Gündoğdu, A. (2015). Measurement of Financial Performance Using TOPSIS Method for Foreign Banks of Established in Turkey between 2003-2013 Years. International Journal of Academic Research in Accounting, Finance and Management Sciences. 5(1):137-147. (Erişim Tarihi: 16.10.2019).

Hwang, C.L. \& Yoon, K. (1981) Multiple Attribute Decision Making: Methods and Applications, A State-of-the-Art Survey. Springer-Verlag. New York. http://dx.doi.org/10.1007/978-3642-48318-9. (Erişim Tarihi: 25.10.2019).

IMF (2006). Financial Soundness Indicators Compilation Guide. https://www.imf.org/external/ pubs/ft/fsi/guide/2006/pdf/fsiFT.pdf. (Erişim Tarihi: 09.09.2017).

IMF (2015). Financial Soundness Indicators and the IMF. https:/www.imf.org/external/np/sta/ fsi/eng/fsi.htm. (Erişim Tarihi: 07.09.2017).

Isik, O. (2019). Türk Mevduat Bankacılığı Sektörünün Finansal Performanslarının Entropi Tabanlı Aras Yöntemi Kullanılarak Değerlendirilmesi. Finans Ekonomi ve Sosyal Araştırmalar Dergisi. 4 (1). 90-99. DOI: 10.29106/fesa.533997. (Erişim Tarihi: 29.02.2020).

Kandemir, T. \& Karataş H. (2016). Ticari Bankaların Finansal Performanslarının Çok Kriterli Karar Verme Yöntemleri ile İncelenmesi: Borsa İstanbul'da İşlem Gören Bankalar Üze- 
rine Bir Uygulama (2004-2014). İnsan ve Toplum Araştırmaları Dergisi. Cilt: 5. Sayı: 7. Sayfa: 1766-1776. (Erişim Tarihi: 16.10.2019).

Karaca, S., Altemur, N., \& Çevik, M. (2019). Bist 30 Endeksinde İşlem Gören Ticari Bankaların Topsis Yöntemi İle Finansal Performans Analizi. Uluslararası İşletme, Ekonomi ve Yönetim Perspektifleri Dergisi. 3(1). 63-73. (Erişim Tarihi: 16.10.2019).

Kenger, M. D. \& Organ, A. (2017). Banka Personel Seçiminin Çok Kriterli Karar Verme Yöntemlerinden Entropi Temelli ARAS Yöntemi İle Değerlendirilmesi. Adnan Menderes Üniversitesi Sosyal Bilimler Enstitüsü Dergisi. 4(4). 152-170. (Erişim Tarihi: 29.02.2020).

Lindgren, C.J., Garcia, G., \& Saal, M. (1996). Bank Soundness and Macroeconomic Policy. IMF. Washington DC.

Opricovic, S., \& Tzeng, G. H. (2004). Compromise Solution by MCDM Methods: Acomparative Analysis of VIKOR and TOPSIS. European Journal of Operational Research. Vol. 156. Issue 2. Ss. 445-455. ISSN 0377-2217. https://doi.org/10.1016/S0377-2217(03)00020-1. (Erişim Tarihi: 24.10.2019).

Pala, F., Ayaydın, H., Çam, A., \& Sarı, Ş. (2018). Türk Bankacılık Sektöründe Performans Değerlendirmesi: AHS ve Topsis Yöntemleri. Global Journal of Economics and Business Studies. 7 (13). 51-64. https://dergipark.org.tr/tr/pub/gumusgjebs/issue/38305/324127. (Erişim Tarihi: 16.10.2019).

Selimler, H. \& Karadağ, M. M. (2020). Türkiye ve Seçilmiş Ülkelerde Mevduat Kabul Eden Kuruluşların Finansal Sağlamlık Göstergelerinin Entropi ve Edas Yöntemi ile Değerlendirilmesi. Florya Chronicles of Political Economy. 6 (1). 79-111. https://dergipark.org.tr/tr/ pub/fcpe/issue/54701/746937. (Erişim Tarihi: 25.06.2021).

TBB (2019a). Bankalarımız 2018. Yayın No: 331. https://www.tbb.org.tr/Content/Upload/Dokuman/7604/Bankalarimiz_2018.pdf. (Erişim tarihi: 25.02.2020).

TBB (2019b). Aktif Büyüklüklerine Göre Banka Sıralaması - 2018 - Aralık. https://www. tbb.org.tr/tr/bankacilik/banka-ve-sektor-bilgileri/istatistiki-raporlar/59. (Erişim Tarihi: 28.10.2019) verilerinden yararlanılarak hesaplanmıştır.

TBB (2019c). İstatistiki Raporlar. https://www.tbb.org.tr/tr/bankacilik/banka-ve-sektorbilgileri/istatistiki-raporlar/59. (Erişim Tarihi: 27.10.2019).

Tunay, K. B. \& Akhisar, I. (2015). "Performance Evaluation and Ranking of Turkish Private Banks Using AHP and TOPSIS," MIC 2015: Managing Sustainable Growth; Proceedings of the Joint International Conference. Portorož. Slovenia. 28-30 May 2015. University of Primorska. Faculty of Management Koper. (Erişim Tarihi: 16.10.2019).

Uludağ, A. S. \& Ece, O. (2018). Türkiye'de Faaliyet Gösteren Mevduat Bankalarının Finansal Performanslarının TOPSIS Yöntemi Kullanılarak Değerlendirilmesi. Finans Politik \& Ekonomik Yorumlar 2018 Cilt: 55 Say1: 637. (Erişim Tarihi: 16.10.2019).

Ural, M., Demireli, E., \& Güler Özçalık, S. (2018). Kamu Bankalarında Performans Analizi: Entropi Ve Waspas Yöntemleri İle Bir Uygulama. Pamukkale Üniversitesi Sosyal Bilimler Enstitüsü Dergisi. (31). 129-141. DOI: 10.30794/pausbed.414721. (Erişim Tarihi: 29.02.2020).

Vergili, G. (2018). BIST’te İşlem Gören Bankaların TOPSIS Yöntemiyle Performanslarının Değerlendirilmesi. Anadolu Üniversitesi Sosyal Bilimler Dergisi. 18 (1). 95-112. DOI: 10.18037/ausbd.550773. (Erişim Tarihi: 16.10.2019). 
Wang, T.C. \& Lee, H.D. (2009). Developing a Fuzzy TOPSIS Approach Based On Subjective Weights And Objective Weights. Expert Systems with Applications. 36. 8980-8985.

Wu, J., Sun, J., Liang, L. \& Zha, Y. (2011). Determination of Weights for Ultimate Cross Efficiency Using Shannon entropy. Expert Systems With Applications. 38 (5). 5162-5165.

Yıldırım, B. \& Demirci, E. (2017). Banka Performansının TOPSIS-M Uygulaması İle Değerlendirilmesi. 1. 35-48. Söke İşletme Fakültesi Priene Uluslararası Sosyal Bilimler Dergisi Cilt:1. Sayı:1. Haziran 2017. (Erişim Tarihi: 16.10.2019).

Zhang, X., Wang, C., Li, E., \& Xu, C. (2014). Assessment Model Of Ecoenvironmental Vulnerability Based On İmproved Entropy Weight Method. The Scientific World Journal, 1-7. ss.2-3. 